\title{
Improving Performance of SMEs through Social Media Marketing Training
}

\author{
Yeni Absah \\ Department of Management \\ University of Sumatera Utara \\ Medan, Indonesia
}

\author{
Yasmin Chairunisa Muchtar \\ Department of Management \\ University of Sumatera Utara \\ Medan, Indonesia \\ Inneke Qamariah, \\ Department of Management \\ University of Sumatera Utara \\ Medan, Indonesia
}

\begin{abstract}
This study aims to investigate the effect of social media training on SMEs performance. Thirty entrepreneurs are used as samples in this survey. Data analysis used in this study is Chi-Square Analysis. This analysis indicates that social media training positively effects SMEs performance.
\end{abstract}

\section{Keywords — Training, Social Media Training, Performance}

\section{INTRODUCTION}

SMEs play a very important role in the economy of a country. The performance and growth of MSME globally is often referred as the driving force for the nation's economic success, which is the first step towards achieving modernization, industry, increasing per capita income, community welfare, improving quality of life, and decreasing unemployment [1]. Even according [2], MSMEs have a greater contribution in reducing unemployment than large companies.

Based on data from the Ministry of Cooperatives in 2012, the current number of MSMEs in Indonesia are around 56.63 million and $98.9 \%$ of MSMEs are micro businesses. This sector contributes $59.08 \%$ to the gross domestic product and absorbing $97.16 \%$ of workforce. This fact proves the contribution given by SMEs to the growth of Indonesian economy. [3].

Like other types of business, MSMEs in Indonesia also suffers impacts from the changes in the business environment globally, such as technological changes and the presence of free trades policy. Technological changes lead to an increase in the quality and quantity of products and services produced, while the free trade policy such as AFTA, ACFTA and MEA creates more competition. The enactment of these agreements in 2015 is a reality that various industry sectors must overcome in the midst of a comparison of market needs with the current industry workforce.

These economic conditions increase the business competition quite significantly. Companies that cannot adapt to these changes will not be able to survive. In order to win the competition, the company must have competitiveness that differentiates from its competitors, so it needs a sustainable competitive advantage strategy for MSMEs.

Medan as the third largest city in Indonesia has considerable potential for the growth and development of SMEs, especially in the field of culinary and fashion. Currently, Medan is known as a tourist destination for culinary and fashion. MSMEs business performance will not work properly, if the SMEs cannot overcome the upcoming competition. The SMEs in Medan should be able to increase business competitiveness in order to compete with its competitors.

In order to compete and subdue the competitors, SMEs should think of something out unique, cheap and easy to utilize. Social media might be just the thing. Social media can be easily altered to suit ones taste and it is cheap.

Unfortunately, a lot of MSMEs are not familiar in using social media and have no strategy to utilize it. Therefore, with insufficient knowledge of social media and how to use it in order to connect with customers, numerous opportunities are missed. This study aims to prove that social media can make a difference in SME's performance by training the owners and employers.

\section{LITERATURE REVIEW AND HYPOTHESIS}

\section{A. Entrepreneurship}

Entrepreneurship is defined as the process of value creation by utilizing a unique available resource to create opportunities [4]. Entrepreneurship can also be explained as an entrepreneurial orientation that demonstrates three dimensions of innovation, pro-activeness and taking calculated risks [4]. Entrepreneurship is the process of creating something new at the value of utilizing time and effort, taking on the financial, physical and social risks, receiving generated monetary rewards, as well as personal satisfaction and freedom [5]. 
Entrepreneurs perform a process called creative destruction to produce a higher value. Therefore, creativity is the core of entrepreneurial skills.

\section{B. Social Media Marketing}

Social media can be defined web-based services that let people to share content and make connections. [6]. [7] proposed that social media marketing creates opportunity for entrepreneurs, small businesses, midsize companies, and large corporations to establish their brands and their businesses.

A basic description social media is "using social media channels to promote the company and its products" [8]. Social media marketing can be in the form giving a coupon or announcing a sale on Facebook or Twitter, or it may include broader brand-building initiatives like communicating with people [7].

\section{SME's Performance}

Organizational performance is a measurement of the success of a company in achieving its objectives. Measurements of organizational performance can be both quantitative and qualitative. Measurements of quantitative performance come in the form of financial achievements (ROE, ROA, ROI), production [number of goods sold, operational cost ratio], marketing [number of customers], and efficiency. Measures of qualitative performance come in the form of discipline, the quality of achievement of goals, the perceptions of leadership on organizational outcomes, individual behavior in the organization, and effectiveness [9].

The idea is also supported by [10], who states that the performance of a business can be classified in 2 aspects, namely the quantitative aspect which is the financial aspect and qualitative aspect which is non-financial aspect [10]. Financial aspects include the level of sales, finance, profitability, productivity, product value added and market share $[11 ; 12]$. The non-financial aspect in question is consumer satisfaction, human resource development and employee job satisfaction $[13 ; 11]$.

[14] classifies several performance measures for small and medium enterprises:

1. Performance measured based on the balanced scorecard and consist of internal business processes, financial innovations and learning and consumers.

2. Performance measured based on Kaiser-Meyer-Olkin [KMO] consists of strategy, productivity, finance, innovation, employee learning, and satisfaction.

3. Performance measured based on performance measurement system consists of financial, quality, employee training, innovation and consumer

\section{Social media Marketing on Business performance}

Social media has important role in marketing and creating relationships with customers. [15] In marketing, MSMEs count on more on the power of word of mouth to win customers [16].

Word of mouth marketing allows customers a reason to talk about products, making it easier for word of mouth to take place. Networking is a broadly quoted marketing activity for MSMEs and essential for establishment, development, and growth [17]

\section{E. Hypothesis}

Based on the description above, the hypothesis can be stated as follows:

There are differences in MSME performance before and after the implementation of competitive strategies for MSMEs

\section{METHODOLOGY}

\section{A. Sample and Data Collection}

The samples of this study are 30 entrepreneurs in culinary, fashion and printing house located near university across Medan.

\section{B. Measures}

To provide an overview of the respondent's demographics [gender, the term of office, level of education, length of work] and description of research variables. This research uses frequency distribution tables that show the value of the distribution of research data and absolute frequency distribution table to show the maximum number, minimum number, average, and standard deviation.

This study also uses Chi-Square Test with the help of SPSS program. It is to find the difference either between two sample data or between multiple sample data.

\section{Analysis and Results}

Table 1. Frequencies and Statistics

\begin{tabular}{|c|c|c|}
\hline \multicolumn{3}{|l|}{ Frequencies } \\
\hline & & $\mathrm{N}$ \\
\hline \multirow[t]{4}{*}{ After - Before } & Negative Differences $^{a}$ & 22 \\
\hline & Positive Differences & 8 \\
\hline & Ties & 0 \\
\hline & Total & 30 \\
\hline
\end{tabular}

a. after $<$ before

b. after $>$ before

c. after $=$ before

Test Statistics
\begin{tabular}{|l|l|}
\hline & After - Before \\
\hline Z & $-2,373$ \\
Asymp. Sig. [2-tailed] &, 018 \\
\hline a. Sign Test
\end{tabular}

MSME's performance can be improved if it is supported by effective training aimed to support the success of the company's vision and mission. One of the trainings necessary for MSMEs especially in the digital era today is training on how to use social media in improving business performance and productivity. 
This training must generate output for MSMEs to be able to utilize social media to the best means of finding innovations, both technology and production as well as increasing the amount of marketing and business expansion.

Based on the research conducted on the perpetrators of SMEs in the Medan on 30 actors of SMEs proves that there are improvements in performance before and after social media training. There are positive and significant improvements in the overall performance of 30 MSMEs after social media training in total. In conclusion, the differential test model does apply to the samples individually, but in average as a group

\section{CONCLUSION AND LIMITATIONS}

Based on the results of the analysis and discussion done in this study, the conclusions are:

1. The results of statistical tests show the differences in MSME performance before and after social media training. This shows that social media training has a positive impact on 30 SMEs in the field of fashion, culinary, printing.

2. The majority of respondents are around 29-33 years of age. And there are 12 respondents with 10-14-year-old business.

Suggestions for this research are:

1. Social media training, human resources training, and marketing training and financial training can improve the performance of SMEs in the city of Medan.

2. Increasing output for business products in the form of innovation both service and technology is expected to improve the performance of SMEs in the city of Medan, especially SMEs in the field of culinary, fashion and printing.

\section{References}

[1] Hassan, T and Ahmad, B, (2016), The Role of Micro Entreprises in Employment and Income Generation: A Case Study of Timergara City Dir (L) Pakistan, International Journal of Economics and Management Sciences, Volume 5, Issue 2.

[2] Farouk, A., and Saleh, M., (2011), An Explanatory Framework For the Growth of SMEs: A System dynamics approach. In Proceedings From International Conference od System Dynamics Society.

[3] Kementerian Koperasi dan UKM, 2010, perkembangan data usaha mikro kecil, menengah dan usaha besar, diunduh dari situs Kemenkop dan UKM.

[4] Morris, M,H., Schindehutte, M., and La Forge, R, W., (2002), Entrepreneurial Marketing : A Construct For Integrating Emerging Entrepreneurship and Marketing Perspectives, Vol 10, No.4, page 1-19

[5] Hisrich, R.D., and Michael P. Peters, 2008. Entreprenuership, Salemba Empat, Edisi 7, Jakarta.

[6] Chaffey et al, (2012); Internet Marketing Strategy: Implementation and Practice; Finance Times/Prentice Hall, Harlow

[7] Gunelius S, (2011), 30 Minutes Social Media Marketing, The next Generation of Business Engagement, Wiley Publishing, Indiana

[8] Barefoot P and Szabo MT (2010) Brand new ventures? Insights on startups' branding practices. Journal of Product \& Brand Management 19(5): 356- 366.

[9] Purnomo R, and Sri Lestari (2010). Jurnal Bisnis dan Ekonomi (JBE); Hal 144-160 Vol. 17, No.2. ISSN : 1412-3126.
[10] Ismail, A., Ridzuan, A. A., Yahya, M. N., Kadir, M. J., Wamin, A., Kuzi, F., Suhaimi, F. F. (2010): Relationship between work stress, supervisor's social support and work intrusion with family conflict. (2010). The 2nd International University Social Responsibility Conference Exhibition(IUSRCE 2010; 2nd USRIC 2010), Oct 5-6, 2010, PWTC, KL/Universiti Teknologi Malaysia.

[11] Neely, A. (2005). The Evolution of performance measurement research. Developments in the last decade and research agenda for the next. International Journal of Operations \& Production Management. Vol 25 No 12, page 1264-1277

[12] Falshaw, J.R., Glaister, K.W. and Ekrem, T. (2006). "Evidence on Formal Strategic Planning and Company Performance. Management Decision", 44(1), pp. 9-30.

[13] Wang, Y. and Lo, H. (2003). "Customer-focused Performance and the Dynamic Model for Competence Building and Leveraging: A Resourcebased View", Journal of Management Development, 22(6), pp. 483-526.

[14] Sousa, S.D., Aspinwal, E.M., and Rodrigues, A.G, 2006, Performance measures in English Small Medium Entreprises: Survey Results. Bencmarking: An International Journal, 13, 120-134.

[15] Adegbuyi O.A, Akinyele F.A and Akinyele S.T. (2015), Effect of Social Media Marketing on Small Scale Business Performance in OtaMetropolis, Nigeria, International Journal of Social Sciences and Management, Vol 2, Issue 3

[16] Stokes D and Lomax W (2002), Taking Control of Word of Mouth Marketing: The Case of an Entrepreneurial Hotelier. Journal of Small Business and Enterprise Development, 9:349-357

[17] Walsh M and Lipinski J (2009) The Role of Marketing Function in Small and Medium Sized Enterprise, Journal of Small Business and Enterprise Development, 16(4): 569-589. 